\title{
Growth and length-weight relationship of Penaeus monodon (Fabricius) cultured in artificial sea water.
}

\begin{abstract}
Post larvae of Penaeus monodon were cultured in a tank with artificial sea water between November 2009 and February 2010. Length and weight of the specimens were taken every seven days interval for the study of growth and length-weight relationship. The overall average growth rate was estimated at $0.36 \mathrm{~mm}$ per day. The mean daily growth rate was 0.53 , 0.33 and $0.27 \mathrm{~mm}$ at the first, second and third month respectively. The mean body weight of the cultured specimens varied from 111.17 to $874.00 \mathrm{mg}$. Average growth of the body weight was estimated at $9.03 \mathrm{mg}$ per day. The relative growth coefficient (b) and condition factor (a) was estimated at 2.94 and 0.00693 . It is reveal that the exponent (b) of Penaeus monodon was very near to the isometric value $(b=3.0)$. So, the growth of P. monodon cultured in tank with artificial sea was isometric. It could be concluded that artificial sea water is feasible for culturing P. monodon when sea water is not available or sea water resource is further away from hatchery.
\end{abstract}

Keyword: Post larvae; Penaeus monodon; Sea water; Growth, P. monodon; Artificial sea water. 